\title{
O IMPACTO SUBJETIVO DA PRESSÃO PSICOLÓGICA INSTITUCIONAL NO COTIDIANO DE PROFESSORAS-MÃES DURANTE O ISOLAMENTO SOCIAL
}

\author{
Marcone Felix Costa \\ Universidade de Pernambuco (UPE), Garanhuns, Pernambuco, Brasil \\ Pedro Henrique de Melo Teixeira \\ Universidade Federal de Pernambuco (UFPE), Recife, Pernambuco, Brasil
}

\begin{abstract}
Resumo: O convívio social foi um dos fatores fortemente afetados durante a pandemia do vírus SARS-Cov-2 (Covid-19), o qual gera grande preocupação nos impactos sentidos. Este estudo faz parte de uma pesquisa transversal, efetuada com professoras-mães, entre 65 a 70 dias do início de isolamento social, em Pernambuco. Foi conduzida por questionário enviado por link e realizada com 30 profissionais de instituições públicas e privadas. O objetivo desta pesquisa é compreender o universo dessas mães enquanto profissionais, sua relação com a verticalidade institucional e seu impacto no cotidiano de isolamento. Os resultados obtidos mostram consequências psicológicas significativas ocasionadas pela pressão sofrida como cansaço, estresse, baixo autoestima, uso de fortes medicações, além da anulação da vida familiar.
\end{abstract}

Palavras-chave: Educação. Professoras. Psicológico. Pandemia.

\section{INTRODUÇÃO}

$\mathrm{Na}$ educação, costumeiramente encontramos a situação de mal-estar atravessando a vida de muitos profissionais em suas práticas e nos laços sociais. No entanto, neste momento em que o mundo passa por diversos desafios encontrados pela disseminação da infecção causada pelo vírus SARS-Cov-2 (Covid-19), outra barreira ainda maior surge com grandes impactos, principalmente na vida dos profissionais de ensino, a dificuldade para que o conhecimento seja acessível a todos.

Mesmo diante de todo o cenário dramático proposto pelo isolamento social, a educação buscou encontrar alternativas rápidas com a chegada da pandemia. Tais alternativas, ainda que incertas sob a ótica da igualdade de acesso a todos e dentro das condições precárias de trabalho para os docentes, fizeram que com que instituições concentrassem esforços em desenvolver estratégias para que as atividades no âmbito educacional não ficassem estagnadas.

Diante desse contexto de mudanças bruscas, muitas professoras tiveram que, urgentemente, assumir o peso das cobranças institucionais para além das demandas sociais - para si mesmas enquanto mulheres e mães -, submetendo-se a condições adversas de trabalho em um breve espaço de tempo, uma vez que essa nova realidade, 
sobretudo com a necessidade de assumir o trabalho remoto on-line, colocou-se de forma imperativa no contexto da pandemia de Covid-19.

\begin{abstract}
Assim, nesse ambiente de profundas e incessantes transformações, as empresas são pressionadas continuamente a encarar novos desafios e a promover mudanças em suas formas de funcionamento, visando sempre à obtenção de resultados econômicos que satisfaçam aos acionistas. As mudanças organizacionais implementadas pelas empresas, objetivando sobreviver em um ambiente socioeconômico em contínuas transformações, ocasionam grande impacto no mundo do trabalho (BACKES, 2012, p. 119).
\end{abstract}

Na dimensão familiar, o mundo do trabalho, principalmente nesse contexto que atravessamos, teve seu acentuado peso. Para muitas profissionais da educação ter que lidar com o ensino remoto e a assistência aos filhos envolveu uma maratona de atividades no espaço doméstico. Problemas que já existiam antes da pandemia, na vida familiar e pessoal dessas trabalhadoras, passaram a abrir novas janelas de preocupações excessivas quando somadas às pressões sociais e institucionais.

Já no plano psicológico, pela intimidação derivada do trabalho remoto, essas profissionais são afetadas emocionalmente ora por tentar suprir as requisições da cria na função materna, ora pela adesão à pressão social e preconceituosa sobre afazeres domésticos. Fruto dessa forte pressão psicológica, elas passam a realizar uma manutenção negativa de um sentimento de culpa profundo, por não dar conta de tantas exigências internas, como as questões sexuais, estéticas, intelectuais e criativas.

Esse tipo de sofrimento ligado ao campo do trabalho se encontra nos processos de mais-valia, os quais se aproveitam da captura subjetiva da trabalhadora para se efetivarem na ditadura do mercado. Isto é, os ditames da ação institucional as levam a viverem em situação de alienação e sofrimento. Assim, não é difícil compreender os dramas que essas mães-docentes passam quando se entende que:"Quanto mais o trabalhador se desgasta trabalhando (ausarbeitet) ... tanto mais pobre se torna ele mesmo, em seu mundo interior, [e] tanto menos [o trabalhador] pertence a si próprio (MARX, 2010, p. 81)".O trabalho enquanto conceito ontológico marxiano é substancial, transforma e satisfaz a necessidade humana, mas pode ser compreendido como objetivação e, ao mesmo tempo, como alienação e negação do homem. Sendo assim, o trabalho educativo e intelectual de professoras aqui exposto pode ser interpretado e vinculado à submissão corporativa da manipulação dos meios e objetos de trabalho, não pode estar excluído da dimensão de proletariado, uma vez que a verticalidade institucional enriquece o dono de escolas e impõe uma sobrecarga de produção para seus lucros.

Corroborando a premissa de que a trabalhadora se desefetive à medida que a mesma produz, e refletindo sobre as condições das mulheres nesse contexto histórico, Harvey (2016), apontando uma contradição importante entre desenvolvimento tecnológico e descartabilidade humana, afirma que: 
COSTA, M. F., TEIXEIRA, P. H. de M.

A maioria da população mundial está se tornando descartável e irrelevante o ponto de vista do capital, o que ampliará progressivamente a dependência da circulação de formas fictícias de capital e construções fetichistas de valor centradas na formadinheiro e no sistema de crédito. Como é de se esperar, alguns segmentos da população são mais descartáveis do que outros, assim mulheres ... arcam com a maior parte do fardo e provavelmente arcarão ainda mais num futuro próximo (HARVEY, 2016, p. 109).

Essa perspectiva de um futuro sombrio para as mulheres, no que concerne à sua descartabilidade no mundo do trabalho, aparece no contexto atual sob a forma de uma precarização mais aguda das condições de vida, a partir das exigências mais acentuadas impostas pelo trabalho ao grupo social das mulheres.

Segundo a ONU Brasil, os grupos de risco que mais devemos assistir neste isolamento são as mulheres em suas profissões, as quais deverão receber um olhar diferenciado pelas instituições, visto que "estão fazendo malabarismos com a educação em casa e trabalhando em tarefas domésticas" (ONU BRASIL, 2020, p. 1). Ainda de acordo com a Organização Mundial da Saúde - OMS, "são o grupo mais vulnerável a problemas de saúde mental durante a pandemia da Covid-19 e mais suscetível a quadros como ansiedade e depressão" (FACULDADE..., 2020, p. 1).

Exaustivamente, professoras no Brasil inteiro se mostram vulneráveis à condição imposta social e profissionalmente dentro de sua própria casa, em um cenário dramático de exigências por excelência didática e dos protestos morais. Com isso, essas mulheres têm expressado visivelmente um esgotamento, não conseguindo existir para si como mulher-mãe-profissional. Instituições, em busca de resultados satisfatórios, exigem e sobrecarregam muitas dessas profissionais sem ao menos dar o suporte adequado para o trabalho ou o entendimento devido à sua condição compulsória, sendo, para essas, fonte de sintomas em massa.

Diante de tudo isso, podemos perguntar: como essas mulheres poderão desempenhar sua maternidade, exercer sua profissão, cuidar de sua vida pessoal, pensar na própria saúde física e emocional e ainda assim se sentirem inteiras?

Observando as bases lançadas pelos estudos de Backes (2012), é visto que o trabalho moderno tem graves riscos à saúde mental:

Por não permitir a livre atividade, torna-se perigoso ao homem. $\mathrm{O}$ bem-estar do trabalhador advém do livre funcionamento, articulado dialeticamente com o conteúdo da tarefa, o que faz diminuir a carga psíquica do trabalho. Para o trabalhador obter o bem-estar no seu trabalho, a energia pulsional necessita ser descarregada no exercício do próprio trabalho para que não seja acumulada no aparelho psíquico. O estilo de vida moderno, que dá maior importância ao racional que o afetivo, que valoriza a competitividade constante e os padrões de qualidade e produtividade, provoca uma série de sofrimentos e deixa os trabalhadores vulneráveis a doenças como o stress, depressão, alcoolismo, desequilíbrio emocional (BACKES, 2012, p. 122-123).

Inter-Ação, Goiânia, v.46, n.1, p. 47-62, jan./mar. 2021. Disponível em: <http://dx.doi.org/10.5216/ia.v45i3.65008>. 
Este artigo é a integração de dois caminhos comunicativos: por um lado corresponde a um aporte teórico que lança bases à relação professora-instituição, na perspectiva de olhar uma psicogenética do sofrimento e da pressão sofrida e, por outro lado, faz parte de um estudo transversal, qualitativo, efetua do com professoras da educação básica entre o período de 65 a 70 dias do início do isolamento social no Estado de Pernambuco.

O objetivo é compreender o universo dessas mães enquanto profissionais e sua relação com a verticalidade institucional, em fontes sintomáticas de adoecimento surgidas pelas exigências decorrentes do formato de aulas remotas, durante a fase de isolamento social. A relevância da discussão aqui proposta inclui a possibilidade de contribuir com um esboço contextualizado para exortar a necessidade de assistência às profissionais da educação, tornando a escola efetivamente um espaço de crescimento profissional e pessoal.

\section{A PRECARIZAÇÃO DO TRABALHO NA EDUCAÇÃO E A ANULAÇÃO DOS IMPULSOS SUBJETIVOS}

O trabalho socialmente organizado, enquanto instituição criada pelo processo civilizatório, diz Freud (1996), não somente "poderia ser entendido como uma via de sublimação das pulsões do sujeito, como também um dos espaços privilegiados para a expressão dos conflitos" (FREUD, 1996, p. 63). É na verdade um confronto entre sobrevivência e angústia, alimentada pela relação instituição-trabalhador, um fator que remete sempre à relação de hierarquia em uma configuração verticalista. Ainda no escrito Mal Estar na Civilização, Freud (2010) menciona de maneira notável que "a atividade profissional constitui fonte de satisfação especial, se for livremente escolhida, isto é, se, por meio da sublimação, tornar possível o uso de inclinações existentes, de impulsos" (FREUD, 2010, p. 81).

Nessa perspectiva, a via de sublimação mostra que o trabalhador exerce sua função como forma de amenizar de tensões interiores, de conflitos inerentes à natureza. Essa condição é própria da relação social. Da mesma forma, quando voltamos nosso olhar para a relação trabalhador-instituição, a empresa opera como elemento determinante na hierarquização, fazendo função paterna na simbolização da castração e na aplicação da Lei.

A empresa, no modo de agir, impacta a subjetividade do trabalhador pela condição de amparo e desamparo, ou seja, ela mantém a figura do provedor paterno, e o trabalhador embasa a condição traumática e erótica da infância. É nesse jogo assimétrico, da relação de desejo e normatividade, entre as ordens da continuidade pulsional e da descontinuidade simbólica, que o sujeito pode criar objetos que possam promover a experiência de satisfação, além de ser a condição para angústia (MENEZES, 2010, p. 114).

Chegamos repentinamente a um novo cenário mundial, cheio de incertezas e incalculáveis prejuízos. Experimentamos "uma nova morfologia do trabalho" (ANTUNES, 2018, p. 27), não apenas pela expansão moderna, mas também na condição surpreendente promovida pela dinâmica da pandemia e de isolamento social. Com um novo itinerário de trabalho durante este tempo e a intensificação obrigatória dos 
trabalhos em casa (home office), as profissionais da educação passaram a enfrentar uma nova dinâmica de relação social e institucional. Abriram a intimidade de suas casas virtualmente a todos os estudantes, seus horários foram muito mais estendidos, tempo integral na frente de uma tela e condições incoerentes de produção a todo custo, isso para dar conta das novas exigências docentes surgidas no contexto pandêmico.

O sofrimento dessas mulheres não pode ser pensado apenas como fator inerente aos estímulos externos (organização do trabalho, infraestrutura, ritmo de produção), "mas precisa também ser abordada a partir da sua relação com o trabalho no tocante a economia psíquica" (SILVEIRA et al., 2014, p. 23). Neste tempo de isolamento, o aumento do fluxo de trabalho para essas profissionais tem sinalizado um maior índice de estresse em uma rotina muito tensa de vida, carregada de barreiras emocionais e também desgastes diante dos antigos imperativos sociais que as perseguem por séculos. A demanda de sofrimento para além da origem marcada pelo modo de inserção social em um sistema de imposições ao gênero é também tácita estrutura vinda da relação institucional que impedem dinâmica subjetiva da promoção a saúde mental em mulheres-mães no mundo do trabalho.

Sobre as condições de trabalho, muito se tem debatido a respeito da captura da subjetividade na educação, da precarização que o mundo moderno/contemporâneo exerce como marca maior em sua rotina e das formas de exploração que levam as mulheres à estafa psíquica dentro do seu cotidiano. Nesse contexto, a investigação das formas produtivas que levam essas profissionais a exaurir suas vidas e se manter em sofrimento tem fundamental importância para o entendimento de dispositivos alienantes e, nesse caso específico, um olhar diferenciado sobre as mães trabalhadoras que estão na educação, por serem conduzidas a um patamar de desalento ampliado tanto por questões históricas como também institucionais.

Antunes (2018) analisa que "a forte pressão com o trabalhador ocorre para atender rigorosas especificações de concorrência, trazendo riscos à saúde do trabalhador" (ANTUNES, 2018, p. 29). Na situação atual, dentro do cenário de pestilência contemporânea em que encontramos incertezas econômicas das instituições principalmente a educação privada que tem pressionado seus profissionais dentro da oferta de qualidade e concorrência - houve, na verdade, uma inversão de valores. A bandeira levantada pelas instituições não foi em vista da movimentação do ensino, nem da preocupação com a saúde profissional, mas, pretendendo não estagnar neste tempo, o marketing da oferta de aulas remotas dava continuidade ao sistema de lucro do mercado. Dessa forma, o que vimos foi crescimento exponencial da educação digital e tendências tecnológicas, com ela a intensificação e precarização das condições de trabalho de muitas profissionais-mães que não tinham condições de adaptabilidade ou flexibilização, mas estavam sendo pressionadas à produção intensa.

Essa condição relacional de uma obrigação a todo custo para forçar níveis de produção, mesmo em meio às condições adversas de uma pandemia, foi um fator de prejuízos à saúde mental de profissionais que são mães. Alves (2008) afirma que:

O capitalismo manipulatório levou à exaustão os recursos de manipulação das instâncias intrapsíquicas do homem, pelas quais se constituem os consentimentos espúrios à dominação do capital nas "sociedades democráticas". O sócio-metabolismo do capital ocorre por meio do tráfico de valores-fetiches, expectativas e 


\begin{abstract}
utopias de mercado que incidem sobre as instâncias intrapsíquicas. $\mathrm{Na}$ medida em que o toyotismo baseia-se em atitudes e comportamentos pró-ativos, a construção do novo homem produtivo utiliza, com intensidade e amplitude, estratégias de subjetivação que implicam a manipulação incisiva da mente e do corpo por conteúdos ocultos e semi-ocultos das instâncias intrapsíquicas (ALVES, 2008, p. 224).
\end{abstract}

Essas instâncias constituem novas formas sutis de domínio, que do ponto de vista biopsicossocial são traços de controle bem mais eficientes no que diz respeito à captura subjetiva e ao esgotamento para essas profissionais. À medida que elas são tomadas psicologicamente pelo fetiche e introduzem "sonhos", passam a encarar o sofrimento como heroísmo ou necessidade, impulsionando-as a uma rotina letárgica.

Alves (2008) afirma que, na sociedade que vivemos, em que a reprodução do capital tem mais importância que qualquer relação humana, as implicações sociais estão fadadas, por suas próprias características metabólicas, a reproduzir uma estrutura que, na medida em que metaboliza a reprodução das riquezas, nega a constituição dos sujeitos, deixando de afirmá-los e efetivá-los enquanto seres sociais.

As formas de poder, apresentadas aqui pelo termo instituição, e diante da condição de isolamento, são as formas manipulatórias, afeiçoadas por empresas educacionais que implicam em subjetividades alienantes, consequência de um novo formato de laço social que privilegia um funcionamento perverso, ou seja, que resulta em um dispendioso exercício da condição de assujeitamento.

$\mathrm{Na}$ instituição, o sujeito em "sua liberdade confunde-se com o desenvolvimento de sua servidão" (LACAN, 1946, p. 102). Essa aplicação ganha brechas para a alienação e a consequente superexploração da força de trabalho, que se baseiam na sujeição das trabalhadoras. Anulando trabalhadores, seja por coerção individual, seja por desmonte da consciência de coletividade, o sistema empresarial hoje impõe "o medo [que] dissolve o sujeito e a subjetividade humana" (ALVES, 2008, p. 95).

As formas extremas de competitividade que o mercado impõe aos trabalhadores, desde a pressão por produtividade e as formas fetichizadas de mercadoria entre outros, são elementos que compõem o conjunto das imposições que ferem a dignidade do trabalho. Essa constante pressão por mudanças e adaptabilidade, sofrida sobre a ameaça de perder seus empregos, provoca em profissionais adoecimentos diversos, à medida que aliena e impede sua efetivação enquanto sujeito.

Nesse sentido, o trabalho, tal como se constitui na sociedade dos valores fetichizados, provoca pobreza material e desamparo psíquico, isso olhando a circunstância de avaliar a posição da relação vertical empregador e empregado na "inserção da práxis educativa na estrutura produtiva e econômica" (FERNADES, 2013, p.2).

Com a valorização do mundo das coisas (Sachenwe/t) aumenta em proporção direta a desvalorização do mundo dos homens (Menschenwelt). O trabalho não produz somente mercadorias; ele produz a si mesmo e ao trabalhador como uma mercadoria (MARX, 2004, p. 80). 
COSTA, M. F., TEIXEIRA, P. H. de M.

Esse tipo de configuração da atividade laboral limita os profissionais ao exercício de uma realização da vontade alheia, já que este produz não para si e sim para os outros, realizando a vontade do empregador, da instituição, o que gera um conflito interno entre a subjetividade daquele que produz (os profissionais da educação) e a subjetividade daquele que compra a força de trabalho (a família do estudante). Há, também nesse contexto, a supressão do desejo profissional, uma vez que essas forças coorporativas e patronais sempre se sobressaem às forças desejantes dos trabalhadores, tornando estes mais um item de seu acervo de ofertas, o que anula de forma coercitiva os impulsos de subjetividade que os efetivam enquanto sujeitos que trabalham e descaracterizam o mundo interno dos profissionais.

RISCOS PSICOSSOCIAIS EM UM TEMPO SUSPENSO: INTERFACE ENTRE A DESEFETIVAÇÃO E O SURGIMENTO DE SINTOMAS

"O mal-estar contemporâneo se inscreve no corpo, na ação e na intensidade, se caracterizando como dor que não pode ser simbolizada" (BIRMAN, 2012, p. 23). É dessa forma que percebemos o estado mental das professoras durante o período de isolamento social. Dor que não consegue entrar na linguagem, não realiza a simbolização, sendo fonte de sintomas que manifestam em seu corpo adoecimento. Para elas, um momento suspenso entre o fazer antigo e novo, retido ao dilema, que extrai a necessidade de uma ação forçosa. Essas professoras-mães foram surpreendidas com um momento ímpar, de transformar sua casa em escola, tanto para dar aulas quanto para acompanhar seus filhos. Esse espaço foi invadido por ocorrências de ansiedade, do medo e da depressão, onde cravou lugar para existir.

As corporações educacionais, tacitamente, para ampliar sua linha de ação nesse contexto pandêmico, passaram a atuar como fator alienante e repressor das pulsões daqueles que trabalham, mantendo interesses próprios apoiados na supressão dos desejos profissionais e sua força de coerção ativa. Nesse sentido:

\begin{abstract}
a organização se apresenta como uma instância recalcante, uma vez que ela se recusa a levar em conta as pulsões, institui uma linguagem que tem por função a canalização dos desejos individuais no trabalho eficaz e no investimento produtivo/profissional, bem como separa os indivíduos no tempo e no espaço visando a reduzir cada um ao estrito papel que the é concedido, para não pôr em risco o funcionamento da organização. Essas separações definem o trabalhador como "homem da organização" e estranho aos seus desejos. Nessa acepção, a organização inibe o processo criador, já que, para ela, é importante que seja feito somente o que está prescrito, nas condições de trabalho e de tempo permitidas. Ao mesmo tempo que ela exige que ninguém faça outra coisa, ela depende eventualmente da criatividade do indivíduo para desenvolver-se (BACKES, 2012, p. 121).
\end{abstract}

A inversão do processo criativo é a tendência para instauração do processo deprimente. Profissionais adoecem cada dia mais pela pressão psicológica sofrida por instituições opressoras que estão associadas à visão mercadológica, perdendo sua forma 
de manifestar profissionalmente suas práticas e o amor pelo seu exercício. O que vem ao encontro das antigas análises de Marx (2008) sobre a desefetivação humana no trabalho que diz:

\begin{abstract}
Em que consiste, então, a exteriorização (Entäusserung) do trabalho? Primeiro, que o trabalho é externo (äusserlich) ao trabalhador, isto é, não pertence ao seu ser, que ele não se afirma, portanto, em seu trabalho, mas nega-se nele, que não se sente bem, mas infeliz, que não desenvolve nenhuma energia física e espiritual livre, mas mortifica sua physis e arruína o seu espírito. $O$ trabalhador só se sente, por conseguinte e em primeiro lugar, junto a si, [quando] fora do trabalho. Está em casa quando não trabalha e, quando trabalha, não está em casa. O seu trabalho não é portanto voluntário, mas forçado, trabalho obrigatório... a satisfação de uma carência, um meio para satisfazer necessidades fora dele... foge-se do trabalho como de uma peste (MARX, 2008, p. 82-83).
\end{abstract}

Quando existe uma pressão institucional em relação ao fazer profissional do trabalhador, as exigências podem influenciar o quadro de sofrimento constante. Durante o isolamento social, professoras da educação básica, na condição de mulheres e mães, experimentam uma sobrecarga em seus afazeres como excesso de tarefas, pressão sobre seu tempo de aula, alimentação de um quadro de repetitividade de assuntos, planejamentos e formação de arquivos para comprovação de aulas dadas e gerenciamento de conflitos com estudantes e família em ambiente virtual. "Estas características do trabalho funcionam como 'estressores', ou seja, implicam em grandes exigências no trabalho, combinadas com recursos insuficientes para o enfrentamento das mesmas" (GUIMARÃES, 2006, p. 99).

Em tempos remotos, encontramos na relação entre "o fazer e ser profissional" um lugar do desamparo. A instituição não ocupa um lugar de segurança. Sobre isso, as próprias profissionais farão seus próprios registros, localizando esse lugar nos desdobramentos de seu sofrimento e o peso que passaram a carregar durante 0 isolamento. Ainda que o sofrimento, a alienação do trabalho, a superexploração da força humana esteja aceito de maneira silenciosa, não podemos deixar de mostrar que são fatores de um sistema de metabolização do capital que imprime marcas de vazio na vida dessas trabalhadoras.

É na direção dessas análises que afirmamos acontecer uma captura da subjetividade e, de forma mais incisiva, em mães que trabalham na educação. A perspectiva que estas profissionais desenvolvem diante da condição de necessidade as deixa mais suscetíveis às estratégias de domínio que o mundo corporativo tem desenvolvido, com cada vez mais velocidade e eficiência. Assim, sendo mais passível ao controle por medo de não conseguir manter o indispensável à cria. Dessa forma:

Esses procedimentos apresentam o assalariado como ator e aliado da empresa, militante em prol de sua causa. Levam ao seu conhecimento as múltiplas exigências da empresa, suas dificuldades, os desafios que ela tem de enfrentar, fazem com que 
COSTA, M. F., TEIXEIRA, P. H. de M.

\begin{abstract}
ele tome consciência do papel que desempenha, da importância de sua disponibilidade, de seu engajamento, da regularidade e qualidade de seu trabalho etc. Dessa maneira, ele é incorporado a uma série de dispositivos que têm dupla função: a da valorização, promoção da pessoa, e ao mesmo tempo de sua incorporação à racionalidade, à filosofia, à cultura, às escolhas de gerenciamento da empresa. O objetivo é que os assalariados, como pessoas em sua individualidade e não como membro de coletivos com contornos e valores incontroláveis, se integrem à política da empresa e a levem adiante (LINHART, 2007, p. 111).
\end{abstract}

O que se pode observar na análise de Linhart (2007) é a sistematização das formas de captura de subjetiva que fazem que trabalhadores se entreguem, além de suas forças, aos objetivos construídos pela instituição/empresa para as quais vendem sua força de trabalho. Ao mesmo tempo em que perdem sua capacidade de sociabilidade, que é um dos elementos fundamentais a saúde mental e ficam cada vez mais isolados e adoecidos.

As questões referentes ao adoecimento mental de trabalhadores estão, sobremaneira, ligadas ao aparato sistêmico de exploração do trabalho, que explora introduzindo na subjetividade de quem trabalha os efeitos da responsabilização para a metabolização do autoesforço e da autovigilância como manutenção da produção, seja esta de que ordem for. Reforçamos essa leitura sobre a realidade trabalhista afirmando que:

A pressão pela capacidade imediata de respostas dos trabalhadores às demandas do mercado, cujas atividades passaram a ser ainda mais controladas e calculadas em frações de segundos, assim como a obsessão dos gestores do capital por eliminar completamente os tempos mortos dos processos de trabalho, tem convertido, paulatinamente, $\mathrm{O}$ ambiente de trabalho em espaço de adoecimento (ANTUNES, 2008, p. 142).

O mesmo autor ainda evidencia que:

Todo o sofrimento que o cerca (o trabalhador) encontra espaço para se desenvolver na medida em que a classe trabalhadora se vê diante de uma organização do trabalho voltada para o controle acentuado de sua atividade... que oscila o tempo todo entre o discurso de valorização e o controle físico e mental extremados (idem, ibidem).

Estamos falando de um sistema inscrito e silencioso de opressão, a partir dessa forma de exploração, daquilo que se denomina organização flexível do trabalho e olhando as condições que essas mães foram expostas na educação. Em tempos de pandemia essas profissionais têm que cumprir jornadas duplas, triplas e intensamente desgastantes num contexto de isolamento social que, por si só, já é fator de adoecimento grave.

Inter-Ação, Goiânia, v.46, n.1, p. 47-62, jan./mar. 2021. Disponível em: <http://dx.doi.org/10.5216/ia.v45i3.65008>. 


\section{O CAMINHO METODOLÓGICO}

Esta pesquisa é um estudo transversal. Foi realizada entre 65 a 70 dias do início de isolamento social em Pernambuco. $O$ processo foi conduzido por um questionário com 20 perguntas, sendo 8 questões objetivas e 12 dissertativas, enviado por link para grupos de Whatsapp de escolas públicas e privadas do setor que abrangem as seguintes Gerências Regional de Educação no Estado: GREAgreste Meridional, GRE Sertão, GRE Metropolitana Sul e GRE Metropolitana Norte.

O estudo foi realizado com 30 profissionais que voluntariamente responderam ao questionário dentro do prazo estipulado de 5 dias e se enquadravam no perfil da pesquisa, sendo vetada 13 respostas posteriores ao prazo dado e 1 profissional que não era mãe e não estava no perfil de nossa análise. Daquelas que estavam regularmente voltadas ao escopo da pesquisa, 11 são profissionais de escolas públicas e 19 são de escolas privadas. As participantes estavam localizadas em várias cidades espalhadas pelo interior do Estado e da capital, a saber: 2 de Angelim, 1 de Belo Jardim, 1 de Caruaru, 13 de Garanhuns, 2 de Jupi, 2 de Pesqueira, 3 de São João, 1 de Sanharó, 3 de Quipapá, 1 de Jaboatão dos Guararapes e 1 do Recife.

Para o tratamento dos dados discursivos colhidos nesta pesquisa, utilizamos a hermenêutica dialética como forma dinâmica de interpretação dos dados coletados que "leva[m] o intérprete a entender o texto, a fala, o depoimento, como resultado de um processo social (trabalho e dominação) e processo de conhecimento (expresso em linguagem) com significado específico" (MINAYO, 1996, p. 227).

Por natureza da condição imposta de isolamento durante a pandemia, o Termo de Consentimento Livre e Esclarecido foi realizado com assinaturas digitais e todos os relatos e respostas foram registrados em nuvem pelo Google Drive para análise posterior dos autores. $O$ estudo também se insere no propósito dos autores realizarem futuros debates sobre a importância de uma rede que acolha profissionais da educação para o acompanhamento no chamado "novo normal", além de pleitear debates no estudo sobre dispositivos institucionais que afetam a vida e dignidade dessas profissionais da educação.

DA ANÁlISE E DISCUSSÃO: RELATOS SOBRE O ISOLAMENTO, SENTIMENTOS E O PESO INSTITUCIONAL

Diante do martírio vivido por essas mulheres, professoras e mães, neste tempo de isolamento, a partir do direcionamento tomado pela demanda de seu sofrimento durante a pandemia, apontaram fatores que incidem diretamente em suas escolhas. São profissionais que padeceram com a demanda institucional, que abstiveram da vida pessoal, mesmo estando no seio da intimidade familiar, e engendraram uma rotina frenética de preparação de aulas filmadas ou on-line, atendimentos incessantes a estudantes, produção interminável de produtos virtuais, além do peso do trabalho doméstico e do cuidado da cria. O que ficou para si?

A pesquisa apresenta apontamentos manifestados pelas próprias participantes como fontes de sofrimento durante este período de isolamento. O perfil dessas 
profissionais aparece em 3 grupos distintos, a saber: 1) em maior parte são mães e mulheres casadas $(80 \%) ; 2$ ) são mães e mulheres divorciadas $(13,3 \%)$ e 3 ) em menor quantitativo são mães solteiras (6,66\%).

No primeiro grupo, mães e mulheres casadas, as profissionais apresentam uma média entre 1 a 2 filhos em idade escolar, entre 2-8 anos de idade. Neste grupo, 17 participantes (56,6\%) relatam um elemento-obstáculo como maior peso, a falta de parceria de seus companheiros. Elas narram que ele, mesmo em casa e fora de expediente, não auxiliavam na monitoria das aulas dos filhos e nem em serviços domésticos para que pudessem ter concentração nas aulas que estavam para administrar. Se comparada às demais profissionais pertencentes aos grupos 2 e 3, percebemos uma amenização do sistema estressor, contudo, ainda vinculadas à demanda da filiação. Os grupos 2 e 3 estão unidos em um mesmo fator, que declaram ser um dos obstáculos que encontraram no trabalho docente: trabalhar em mesmo ambiente e mesmo horário que os filhos em aula. Essas professoras, para reduzir este sobrepeso, contavam com o auxílio de familiares próximos como avós, irmãs e tias para a monitoria dos filhos, mas com grandes óbices desses tutores assistirem devidamente às dificuldades encontradas pelos filhos em relação às aulas híbrido-remotas.

Esses três grupos possuem dramas semelhantes, mas diferem na forma gerencial. Visivelmente, como mostram os dados acima, no primeiro grupo mais da metade das profissionais casadas atravessam um modelo de negligência androcêntrica, em que a prole é destituída do acolhimento e das responsabilizações paternas, mesmo que os pais estejam dentro da própria casa. Essas mulheres estão desamparadas e inseridas em um modelo ideológico machista em que encontram dificuldades para crescer como mulher e profissional. Já as divorciadas e solteiras passam a ser amparadas por familiares que estejam mais próximos. Essa condição tem peso na forma de conduzir a criação dos filhos, uma vez que tutores transferem afeto e influenciam comportamentos, porém transparece que divorciadas e solteiras têm possibilidade maior na produção de aulas remotas e outras necessidades vinculadas à profissão.

Percebemos que as professoras-mães-solteiras ou divorciadas tendem à condição de enfrentamento maior que as professoras-mães-casadas. Em todo caso, para todos os perfis aqui mencionados, as condições de atividade laboral e de atividades no cuidado com a prole causam maior desgaste e têm grande impacto emocional nas mesmas, produzindo sentimentos relacionados à culpa.

Por segurança, para expor suas respostas ao texto sobre seus sentimentos, as participantes terão nomes velados por siglas para manutenção do sigilo das informações. Trazemos fragmentos representativos do grupo em geral. Perguntamos a elas como estavam sentindo a demanda institucional. Das 30 respostas obtidas, sendo 18 de escolas privadas e 5 de escolas públicas, 23 (76,6\%) expressam o mesmo sentimento em relação à pressão sofrida. Abaixo um fragmento do texto das respondentes:

\footnotetext{
Imensamente pressionada. Estamos com prazos curtos, desorganização de horários, dentre outros fatores que afetam o psicológico (A.S.S).
}

A demanda aumentou e a adaptação está sendo difícil. O que interessa para a escola, pais e responsáveis é a aula pronta, o 

(I.D.S.S.B.S)

O tempo todo. Recebemos cobranças, mensagens com demanda das famílias, da escola, dos alunos. Por vezes ouvimos críticas em relação ao tom de voz, a seleção de vocabulário ou até mesmo sobre a cor da parede do local onde ministramos as aulas (J.S.C).

Não havia outra solução, era encarar a situação ou permitir que alguém ocupasse o seu lugar (W.B.).

As declarações mostram o cansaço, o estresse e a desmotivação. São três elementos sintomáticos que encabeçam adoecimentos. Essas profissionais lidam com a chegada do novo e narram uma opressão por dois lados, institucional e das famílias que compõem a comunidade escolar. As cobranças em ambas as partes abrem lugar para que elas intensifiquem o tempo de trabalho para dar conta das expectativas dos outros. Dessa maneira, manifesta o tácito esquema alienativo psicológico de anulação do repouso e da vida para suprir a demanda. Somente anulando seu tempo, seus filhos, elas conseguirão responder às expectativas impostas pela condição institucional e de mercado atual.

"Não há nada mais destrutivo do que a vida anulada e contrariada por esperanças frustradas" (REICH, 1953, p. 9). Notamos que as exigências institucionais, principalmente das empresas privadas, sufocam o fazer e a liberdade das profissionais. Transparece nos relatos que a consequência dessa pressão sofrida impacta diretamente a sua forma de se enxergar no mundo e de agir no cotidiano.

Diante desse quadro apresentado, percebemos que a chegada do ensino remoto ajustado às exigências institucionais e sociais é, lamentavelmente, desvantajosa à saúde mental dessas mulheres. É preocupante tal situação, uma vez que vem aumentando quadros de afastamentos trabalhistas por condição depressiva em profissionais da educação. Dentre as novas formas de subjetivação, a depressão tem se destacado em função de um aumento significativo desse diagnóstico e previsões de que a sociedade futura será predominantemente depressiva (KEHL, 2009; MENDES, 2014, p.424).

Quando perguntamos a essas profissionais sobre como elas se percebem durante o isolamento, podendo ter mais de uma resposta, em predominância aos achados encontramos claramente fatores pré-dispositivos à depressão. Sobressaíram os sentimentos de impotência (48,3\%), ansiedade $(17,4 \%)$, vazio $(13,8 \%)$, tristeza $(10,3 \%)$ e outros ainda, como a incapacidade $(3,4 \%)$, cansaço $(3,4 \%)$ e desânimo $(3,4 \%)$. Apenas uma participante não responde aos itens supracitados. No geral, essas respostas são alarmantes quando estes fatores passam a ocupar um lugar no fazer profissional e manifestam a fragmentação subjetiva dessas mulheres.

Quando perguntadas sobre este tempo que estão vivendo, 29 respostas foram obtidas, uma abstenção apenas, as participantes resumem em totalidade como mostra o fragmento abaixo: 
COSTA, M. F., TEIXEIRA, P. H. de M.

\author{
Uma mistura de dúvidas, incerteza, caos, desespero, calmaria, \\ reconhecimento e loucura... Tudo misturado (M.T.C). \\ Como uma maratona surreal (J.S.C).
}

Sem motivação (P.G.A.S).

Elas manifestam oscilações emocionais e narrativas predominantemente negativas. As dúvidas surgem como produto de uma ansiedade. Neste tempo de isolamento, tudo é incerto, lidamos com imprevisível em todos os momentos. Dessa forma, a possibilidade da via do possível fica distante e a experiência emocional mais frágil.

Outro achado importante é que, das 30 profissionais que participaram, 22 $(73,3 \%)$ disseram não buscar ajuda em terapias, e sim procuraram alívio ao sofrimento em uso de medicamentos. Destas 22 participantes, 17 são casadas (70,8\%), 4 divorciadas (100\%) e 1 solteira (50\%). O primeiro grupo das mães e mulheres casadas, unido ao grupo 2, das mães e mulheres divorciadas, anteriormente analisado, tendem em maior parte à fuga medicamentosa como solução emergente.

$\mathrm{Na}$ lista que as participantes preencheram aparecem nomes de vários ansiolíticos prescritos e com uso sem prescrição como Alprazolam, Rivotril e Clonazepam, que são medicações responsáveis por diminuir a excitação, agitação e tensão, trazendo relaxamento, sonolência e sensação de calma. Outras medicações que aparecem na lista dos relatos são os antidepressivos como o Alenthus, para o tratamento da depressão com ansiedade associada. E ainda aparecem outros nomes de relaxantes naturais por elas citados como Seakalme e Valeriamed.

Esse é um reflexo muito visível na pandemia sobre o aumento da procura de fármacos. No entanto, entre as profissionais da educação em período de isolamento, em relação à circunstância apresentada de pressão psicológica sobre as trabalhadoras, houve uma produção intensa e sistêmica de sujeitos medicalizados e letárgicos. Nessa corrida transtornada entre vida pessoal e profissional, no processo marginal entre aulas remotas e a ocupação com os filhos, essas mulheres passaram a negar seus próprios desejos e dopar a pressão sofrida com tais medicações.

\title{
CONSIDERAÇÕES FINAIS
}

O aumento da pressão psicológica durante o confinamento tem fragilizado a vida de muitas professoras que exercem a maternidade. Tacitamente, elas são vítimas de incompreensões institucionais e de um exercício sem adaptações à sua realidade enquanto mulher e mãe. Percebemos que, assim como nesta pesquisa, tantas outras professoras estão sendo submetidas a jornadas de trabalhos intensas, sob o discurso da qualidade e dos resultados, o que ancora uma situação de pressão social, intensificação do trabalho e alienação. O desdobramento aparente dessas contradições aparece na forma de sintomas depressivos, dor, angústia, desespero e mal-estar, que passa a transitar no cotidiano das trabalhadoras da educação como discurso de normalidade. Este conjunto de sentimentos apresentados, que formam o sofrimento psíquico dessas trabalhadoras, é uma particularidade silenciosa das formas de exploração do trabalho 
que, visando exclusivamente ao ganho institucional, despreza o ser humano e a sua dignidade em nome do lucro e geração de poder.

"A vida, tal como nos coube, é muito difícil para nós, traz demasiadas dores, decepções, tarefas insolúveis" (FREUD, 2010, p. 28). Para isso, a instituição empregadora necessita enxergar seus profissionais para além da condição produto, o que, dentro do contexto da própria estrutura de exploração do capital, se torna improvável, uma vez que está na própria essência de reprodução desse sistema a exploração do trabalho, causa esta da condição de adoecimento que acomete trabalhadores.

O resultado da pesquisa alerta as instituições para a necessidade de apoio multiprofissional e políticas públicas que ajudem as profissionais a encontrarem uma narrativa de possibilidades na promoção da saúde mental. A relação com as profissionais-mães não necessita da exploração ao modo de vida, o trabalho deve ser edificante, precisa apresentar uma condição de dignidade em relação à real natureza da mulher-mãe-profissional.

Por fim, cada instituição educacional, privada ou pública, diante da circunstância de isolamento e da perspectiva de um "novo normal" poderá, com o seu projeto de reabertura, prever o fortalecimento do apoio psicológico e multiprofissional a suas profissionais, especialmente às mães, pela dimensão do impacto que estão sofrendo e as consequências do isolamento. Sem esse apoio, as dificuldades poderão perdurar na instituição e na vida das profissionais, com quadros depressivos intensos, revelando, assim, a silenciosa adesão institucional à opressão de trabalhadoras.

Artigo recebido em: 14/08/2020

Aprovado para publicação em: 30/12/2020

THE SUBJECTIVE IMPACT OF INSTITUTIONAL PSYCHOLOGICAL PRESSURE ON THE DAILY LIVES OF TEACHER-MOTHERS DURING SOCIAL ISOLATION

ABSTRACT: Social interaction was one of the factors strongly affected during the SARS-Cov- 2 virus (Covid-19) pandemic, which is of great concern today in terms of the impacts felt. This study is part of a cross-sectional, qualitative research, carried out with teacher-mothers, between 65 and 70 days from the beginning of social isolation in Pernambuco. It was conducted through a questionnaire sent by link and carried out with 30 professionals from public and private institutions. The objective of this research is to understand the universe of these mothers as professionals, their relationship with institutional verticality and their impact on the isolation routine. The results obtained show significant psychological consequences caused by the pressure suffered such as tiredness, stress, low self-esteem, use of strong medications, in addition to canceling family life.

KEYWORDS: Education. Teachers. Psychological. Pandemic. 


\section{EL IMPACTO SUBJETIVO DE LA PRESIÓN PSICOLÓGICA INSTITUCIONAL EN LA VIDA COTIDIANA DE LAS MADRES-MAESTRAS DURANTE EL AISLAMIENTO SOCIAL}

RESUMEN: La interacción social fue uno de los factores fuertemente afectados durante la pandemia del virus SARS-Cov-2 (Covid-19), que hoy es motivo de gran preocupación por los impactos que se sienten. Este estudio es parte de una encuesta transversal, realizada con madres maestras, entre 65 y 70 días antes del inicio del aislamiento social en Pernambuco. Se realizó mediante un cuestionario enviado por enlace y realizado con 30 profesionales de instituciones públicas y privadas. El objetivo de esta investigación es comprender el universo de estas madres como profesionales, su relación con la verticalidad institucional y su impacto en la rutina de aislamiento. Los resultados obtenidos muestran importantes consecuencias psicológicas provocadas por la presión sufrida como cansancio, estrés, baja autoestima, uso de medicamentos fuertes, además de anular la vida familiar.

PALABRAS CLAVE: Educación. Docentes. Psicológicos. Pandemia.

\section{REFERÊNCIAS}

ALVES, G. A. P. A subjetividade às avessas: toyotismo e" captura" da subjetividade do trabalho pelo capital. Cadernos de psicologia social do trabalho, v. 11, n. 2, p. 223-239, 2008.

ANTUNES, R.O privilégio da servidão: o novo proletariado de serviço na era digital. Boitempo editorial, 2018.

BACKES, A. L. Trabalho e subjetividade: sofrimento psíquico em contexto de mudanças organizacionais. Gestão e Sociedade, v. 6, n. 14, p. 117-138, 2012.

BIRMAN, J. O sujeito na contemporaneidade: espaço, dor e desalento na atualidade. Rio de Janeiro: Civilização Brasileira, 2012.

FACULDADE DE MEDICINA DA UFMG. Pandemia compromete saúde mental das mães. Disponível em: https://www.medicina.ufmg.br/pandemia-compromete-saude-mental-das-maes/. Acesso em: 29 maio 2020.

FERNANDES, L. V. O trabalho docente à luz da perspectiva histórico-dialética. In: 36a Reunião Nacional da ANPEd, GT09 Trabalho e Educação, Goiânia, 2013, p. 1-13. Disponível em: https://anped.org.br/biblioteca/item/o-trabalho-docente-luz-da-perspectiva-materialistahistorica. Acesso em: 29 maio 2020.

FREUD, S. O futuro de uma ilusão [1927]. In. FREUD, S. Obras completas de Sigmund Freud: edição standard brasileira. Rio de Janeiro: Imago, 1996. v. XXI.

FREUD, S. O mal-estar na civilização, novas conferências introdutórias à psicanálise e outros textos (1930-1936) / Sigmund Freud: tradução Paulo César de Souza - São Paulo: Companhia das Letras, 2010. 
GUIMARÃES, L. A. M. Fatores Psicossociais de Risco no Trabalho. In: Anais do $2^{\circ}$ Congresso Internacional sobre Saúde Mental no Trabalho - Artigos de Palestrantes. Goiânia, 2006.

HARVEY, D. 17 contradições e o fim do capitalismo/ David Harvey; tradução Rogério Bettoni. 1.ed. - São Paulo: Boitempo, 2016.

LACAN,J. Formulações sobre a causalidade psíquica [1946]. In: LACAN, J. Escritos. Rio de Janeiro: Zahar, 1998.

LINHART, D. A desmedida capital. Tradução de Wanda Caldeira Brant. 1 ed. São Paulo: Boitempo, 2007. MARX, K. Manuscritos econômicos-filosóficos. São Paulo: Boitempo, 2010.

MENDES, E. D. Melancolia e Depressão: Um Estudo Psicanalítico. Psicologia: Teoria e Pesquisa. Out-Dez 2014, Vol. 30 n. 4, p. 423-43.

MENEZES, L. Um olhar psicanalítico sobre a precarização do trabalho: desamparo, pulsão de domínio e servidão. 2010. 233 f. Tese (Doutorado em Psicologia) - Instituto de Psicologia da Universidade de São Paulo, São Paulo.

MINAYO, M C S. O desafio do conhecimento. Pesquisa qualitativa em saúde. 4 ed. São Paulo: Hucitec-Abrasco, 1996.

ONU Brasil. OMS: O impacto da pandemia na saúde mental das pessoas já é extremamente preocupante. Disponível em: https://nacoesunidas.org/oms-o-impacto-da-pandemia-na-saudemental-das-pessoas-ja-e-extremamente-preocupante/amp/. Acesso em: 14 maio 2020.

REICH. W. Oassassinato de Cristo. São Paulo: Martins Fontes, 1953.

SILVEIRA, L. C. A escuta do sofrimento psíquico relacionado ao trabalho: contribuições da psicanálise para o cuidado em saúde. Psicologia em Revista, Belo Horizonte, v. 20, n. 1, p. 19-33, abr. 2014.

Marcone Felix Costa: Doutorando em Psicologia Social pela UFPB. Mestre em Psicologia, Práticas e Inovações em Saúde Mental. Especialista em Saúde Pública. Pesquisador CNPq e membro do Grupo Internacional de Pesquisas em Políticas, Práticas e Gestão da Educação pela Universidade de Pernambuco - UPE. Orcid: https://orcid.org/0000-00022194-6319

E-mail: marconefelixcosta@yahoo.com.br

Pedro Henrique de Melo Teixeira: Doutorando em Educação pela Universidade Federal de Pernambuco - UFPE. Professor no Instituto Federal de Educação Ciência e Tecnologia de Alagoas - IFAL. Orcid: https://orcid.org/0000-0002-9316-3137

E-mail: professorpteixeira@gmail.com

Este periódico utiliza a licença Creative Commons Attribution 3.0, para periódicos de acesso aberto (Open Archives Iniciative - OAI).

Inter-Ação, Goiânia, v.46, n.1, p. 47-62, jan./mar. 2021. Disponível em: <http://dx.doi.org/10.5216/ia.v45i3.65008>. 